\title{
SOBRe A MOTIVAÇÃo MOderna de CRÍTICA À METAFíSICA*
}

\author{
[ON THE MOTIVATION OF MODERN CRITICAL TO METAPHYSICS]
}

\author{
Miguel Antonio do Nascimento **
}

Resumo: Este artigo consiste em abordagem de cunho introdutório sobre a crítica à metafísica. Destacam-se elementos isolados do conteúdo de crítica à metafísica na modernidade e que tende a vir a ser desenvolvido na contemporaneidade. Com isso quer-se dizer que na passagem da modernidade para a contemporaneidade a filosofia acaba por incorporar o conteúdo de crítica à metafísica e evolui na direção de vir a reconhecer sua condição de ser metafísica e de empreender crítica a essa condição. Para estabelecer a abordagem do assunto procura-se aqui manter subjacente a ideia de crítica à metafísica no contexto da história da filosofia; mas é priorizado nisso o aspecto temático em vez de seu aspecto histórico. Busca-se mostrar que no processo de compreender a crítica à metafísica tem ocorrido de se tentar apartar do caráter de metafísico o caráter de teórico da ciência. Requer então indagar se é possível estabelecer marco de separação entre uma coisa e a outra. Em vez de separação opta-se aqui por investir no conhecimento da identidade da própria metafísica como saber filosófico; busca-se esclarecer que a pergunta pelo que é filosofia e a dificuldade de compreender o seu conteúdo é o que traz à tona a crítica à metafísica e a torna necessária, mas como modo de se compreender melhor o que é filosofia.

Palavras-Chave: Crítica à metafísica; Saber filosófico; Saber teorético
ABSTRACT: This article consists of an introductory approach to the criticism to metaphysics. Highlighting isolated elements of the critical content to metaphysics in modern times and that tends to come being developed nowadays. With this is meant that the passage from modernity to contemporaneity, philosophy turns out to incorporate the critical content to metaphysics and evolves in the direction of come to recognize their condition to be metaphysics and undertake criticism to this condition. To establish the approach to the subject looking here to keep underlying the idea of critique of metaphysics in the context of the history of philosophy; but it is prioritized the thematic aspect rather than its historical aspect. Seeks to show that the process of understanding the critique of metaphysics has been to try to depart from the metaphysical character of the theoretical character of science. Requires then ask whether it is possible to establish the framework of separation between one thing and another. Instead of separating one chooses here to invest in the knowledge of their own metaphysical identity as philosophical knowledge; seeks to clarify the question for what is philosophy and the difficulty of understanding its contents is what brings out the critique of metaphysics and is necessary, but as a way to better understand what is philosophy.

KEYwORDS: Critique of metaphysics; Philosophical knowledge; Theoretical knowledge 
A expressão "crítica à metafísica" aparenta adequar-se mais à filosofia - contemporânea e moderna do que à filosofia medieval e antiga. No entanto, o saber filosófico, desde sua autodeterminação como metafísica, segue já o formato de crítica a si mesmo. O título "metafísica" porta a noção de ultrapassar e ir além de, no sentido de autocrítica. Seria de se dizer que, ao nos referirmos à metafísica, no fundo estamos a tratar tão só do conhecimento filosófico como tal. O nome metafísica, tomado por esse ângulo, aparenta significar o que conhecimento filosófico quer exprimir. Neste caso vale mencionar a informação muito usual de que este termo foi empregado para título de 'filosofia primeira' ou 'ciência primeira'; mas deve-se acrescentar que foi empregado já depois que o conteúdo da filosofia enquanto o tipo de conhecimento que é, desde sempre lhe correspondeu. A título de exemplo devemos dizer que Aristóteles o reconhece já em seus antepassados, atribuindo-o a "homens" que, como Tales [de Mileto] e Anaxágoras [de Clazômenas], não tinham por alvo as coisa úteis e vantagens, mas "coisas ímpares, admiráveis, difíceis e prodigiosas..." (ARISTÓTELES [1141b2], 2011, p. 292). Devemos considerar que isso pôde ter sido possível deste modo, ou seja, foi feito valer o termo criado como expressão do conteúdo filosófico aristotélico e, por extensão, como a definição de metafísica também ${ }^{1}$. Tal conteúdo, porém, não nasceu com Aristóteles e a metafísica não se restringiu a ele. Assim, o conteúdo de filosófico que chegou a Aristóteles procedendo de Platão, e mesmo desde Parmênides e dos demais filósofos anteriores, permanece então em coexistência com a designação "metafísica". A partir deste fato, o próprio termo "metafísica" deveria, no decorrer da história da filosofia, nos fazer alcançar não só o filosófico aristotélico encaminhado como "metafísica", mas também todo aquele outro conteúdo de filosófico coexistente. Neste ponto convém novamente aludir ao fato de Aristóteles tratar primeiro das 'coisas físicas', sabendo que são 'posteriores segundo a

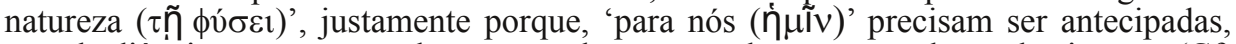
em obediência ao compreender - no ordenamento do processo do conhecimento (Cf. REINER, 2009, p. 97). Deve-se acrescentar aqui que dois elementos residem no conteúdo da expressão 'para nós (ท่นĨv)': [a] a condição de compreender o conteúdo de primeiro e princípio do que é por si e anterior; [b] a condição de tornar possível viabilizar através do conhecimento da natureza a verdade do princípio primeiro. Enquanto o elemento [b] é consequente em relação ao [a], este último, ao contrário, é propriamente o homem - o poder da razão. Por este ângulo, ter acesso ao que é primeiro e pensá-lo assim, isto se impõe independentemente da condição de assegurar sua validade objetiva. Então também por este ângulo, todo o pensar do antes, do dentro e do fora da designação de metafísico coexiste aí como saber filosófico. Precisamente por isso - por causa da dificuldade relativa a essa confusa mistura e necessidade de garantia para validade e verdade do filosófico enquanto tal - pareceu e resultou conveniente definir e estabelecer os limites do conhecimento filosófico enquanto metafísica. Do contrário, ter-se-ia de compactuar com o caráter paradoxal intrínseco à dificuldade que é ter de contar com o posterior para partir e ir até atestar o que é anterior, primeiro e por si. Isso é contornado uma vez que se conta com um dispositivo que faculta ultrapassar este impasse com êxito e indicar a direção correta a tomar. É isso que nos mostra Aristóteles relativamente à "percepção sensível" na base de todo saber. Ele dá este esclarecimento: "O mais distante dela é o mais universal, o mais próximo dela é o particular" (Apud REINER, 2009, p. 96)². O conteúdo de "universal” aparece como o norte que a metafísica toma por direção, isto é toma pelo sentido, ele todo e único - na modernidade é ainda essa perspectiva com que se pretende criticar a própria metafísica. Em definitivo não se tentou atingir o anterior e primeiro pelo abolir a relação lógica de resultante do que precisou ser considerado como ponto de partida e ida até constatar sua verdade. Dito isso assim até aqui, pode-se agora compreender que o que se quer dizer por metafísica não teria de corresponder necessariamente - sem equívocos e erros - ao conteúdo estabelecido nem de conseguir exprimi-lo. Assim, o termo "metafísica" serviu de recurso para alguém categorizar o conteúdo do próprio 
conhecimento filosófico, mas não já e necessariamente para assegurar a compreensão de tudo o que este conteúdo do saber filosófico tem a comunicar em seu significado fundamental. A filosofia, pois, condicionada à categoria de metafísica e não igualmente também à ambiguidade complexa de seu conteúdo, deixa-se então instituir como um conhecimento capaz de explicar e definir as coisas, tal qual a ciência é capaz de fazê-lo, dada a condição de categoria do conhecimento a que corresponde. Mas no que alguém torna comum essa mesma base, ao fazê-la ser também a do conhecimento filosófico, torna a filosofia, enquanto metafísica, estéril: ela não consegue corresponder a esta mesma base de definir as coisas e, assim, perde em competência relativa a isso. Neste sentido de incapacidade pode-se concordar com acusação crítica à metafísica: como conhecimento filosófico, a metafísica seria um exercício de transcender infértil. Mediante tal ponto de vista supõe-se poder partir de outra base, não metafísica, e se manter nela. Seria uma procedência contrária a da metafísica e, nesta condição seria também justificada como distanciamento e independência do conhecimento metafísico. Sobretudo, este entendimento seria impulsionado pelo êxito com que a ciência consegue se mostrar capaz de explicar as coisas. Conclusão: Por este viés de entendimento incompleto sobre o conteúdo de metafísica e crítica correspondente, devemos admitir enfim que a crítica à metafísica tenha tido de se adequar à concepção de crítica adotada pela filosofia no passar da modernidade para a contemporaneidade. Se se aceita que esta é a forma como tem sido pensado o conteúdo da metafísica, podese também ter em vista outra perspectiva para a reflexão do assunto em causa: no momento em que se recorreu à metafísica para categorizar a filosofia como conhecimento entre outros, deixou-se ao mesmo tempo de ir para além disto e investir na compreensão de tudo o que este conteúdo do saber filosófico consiste fundamentalmente. No caso, a expressão "crítica à metafísica" teria de ser entendida como necessidade de se recobrar a compreensão mais originária do conteúdo de filosofia. Esta seria a base para se estabelecer vínculo de identidade entre crítica à metafísica e conhecimento fílosófico. É isto agora o que deve ser proposto e tornado relevante como o assunto a ser debatido.

É preciso dizer que resultou diferença entre conteúdo da "metafísica" e sua função de título relativo à "fillosofia primeira". Predominou como designação de metafísica, por fim, a abrangência de todo o modo de pensar com vistas a se conseguir compreender princípio e exprimi-lo. Na história da filosofia, como se sabe, a metafísica se encontra vinculada às demais formas de conhecimento. Particularmente a partir da modernidade, isso cai na exigência de uma coisa expressar distinção em relação à outra. Por isso também, ao passar da modernidade para a contemporaneidade, a filosofia pôde ser compreendida sob o modo de crítica à metafísica. Mas a noção e necessidade de crítica à metafísica não ocorre senão em razão da dificuldade de a filosofia se justificar como metafísica e continuar sendo isto. Não se trata de independência e êxito verdadeiros em relação à metafísica.

Em vista disso, será que seria possível e cabível não estabelecer, nitidamente, vínculo entre a metafísica e outra forma de saber? Em caso positivo, não seria justificável somente em razão de explicar e aprofundar mais a compreensão sobre a metafísica em sua origem e identidade? Se não se toma esta via, mas a de se estabelecer uma diferença nítida entre uma coisa e a outra, não se pretende, portanto, explicar de que forma estes saberes se encontram unidos e o que significa apartá-los. Mas, não é justamente isso o mais importante a fazer? De todo modo só mais tarde é que este outro aspecto desta questão consegue ser também considerado como merecedor de interesse e investigação ${ }^{3}$.

A partir de se reconhecer e avaliar a abrangência da metafísica é que se pode dizer de fato em que medida se deve falar em interdependência entre a metafísica e os demais saberes, bem como poder falar em não-metafísico e em superação da metafísica. Neste sentido devemos dizer, por exemplo, que as extensões e influências subsequentes da crítica à metafísica feita por Hume e Kant, enquanto cientificismos positivistas, não 
devem conseguir êxito em desvinculação entre filosofia metafísica e ciência. Isso ajuda a tornar mais claro que, o essencial nesses dois filósofos não é visa primordialmente a uma extinção da metafísica.

A abordagem da crítica à metafísica deve mostrar que a atividade de pensar deve ser compreendida e definida como algo para além da designação da própria metafísica; este caráter da crítica à metafísica não se confunde com propósito de aniquilar a metafísica a favor ou contra a filosofia. Por isso passa a interessar expor sempre mais a implicação entre metafísica e os demais domínios do saber, para se avaliar até onde é possível falar em não-metafísico e em para além da metafísica.

É inerente ao conteúdo da "metafísica" o poder com que o homem estabelece aquilo que tende a ser superado. É isto que se quer dizer, por exemplo, em relação ao fato de Tales de Mileto ter sido caracterizado como o primeiro filósofo. Tales toma emprestado o conceito de água e postula o caráter de unidade para ser condição de manter como todo a diversidade. Com isso ele estabelece mecanismo de cientificidade, para fazer valer nisso o poder abstrair da multiplicidade, ao mantê-la permanente na unicidade da totalidade; esta abstração de totalidade única resulta alcançada, nesse mecanismo, como uma superação metafísica do diverso.

O elemento de cientifico aí é só tomado emprestado e não feito valer, ele enquanto tal, como o teor do filosófico. Em tal condição, esta demonstração de origem da filosofia faz parecer às vezes que indica não o modo de ser do conhecimento filosófico e sim o que poderia e precisaria ser depois - na contemporaneidade -, extirpado por ter surgido de modo metafísico. Entra em jogo nisso uma necessidade ambígua - [a] principio e base para acesso à condição de universal para verdadeiro ${ }^{4}$, mas também [b] possibilidade para a contemporaneidade desmascarar e extinguir o que aprisiona ao caráter de metafísico este conteúdo verdadeiro proveniente do caráter de universal. No entanto, este ponto de vista mesmo, pode expressar algo diferente disso: ele próprio permanece continuamente a indicar também que é mais fundamental explicar o fato de algo - o conhecimento humano - ter dependido do saber metafísico para conseguir se exprimir; o que, justamente por isso, nunca pôde deixar de ser metafísico.

Sendo assim, seja num caso ou noutro não se trata tanto de se precisar acusar a metafísica e sim de acusar nossa dificuldade de explicar por que ter a filosofia de depender da metafísica para poder ser filosofia e não simplesmente ser só ciência. Tal coisa é que não sabemos bem o que é, e sua origem não se encontra, necessariamente, num pensador determinado, a exemplo de Tales de Mileto ou em Aristóteles ou em outro qualquer denominado "metafísico". Se não é levado em conta esta perspectiva como reflexão, então torna-se difícil justificar a necessidade da crítica à metafísica, ou seja, torna-se mais difícil fazer resultar explicado o que se quer que deixe de ser metafísico na natureza da filosofia.

A amplitude disso não está contemplada na presente abordagem. Aqui está sendo apenas tangenciada a dificuldade de se compreender a necessidade de crítica à metafísica Esta dificuldade está sendo referida aqui tendo em vista certo enfoque lógico, relativo a isso, que se costuma dar ao século XVIII, especialmente quanto à marca de novo modo de pensar, intrínseco à modernidade. No caso, o que delimitamos por este novo modo de pensar não é já uma operação de crítica à metafísica e sim elementos de base e preparação daquilo que vai se desenvolver mais tarde como modos de se atingir a metafísica criticamente. O que identificamos como conteúdo fílosófico dessa época, o iluminismo, convém ser tomado mais como distanciamento e dificuldade do que como entendimento crítico com referência à natureza da metafísica. Nesta linha de raciocínio, a crítica iluminista enquanto reflexão filosófica é só um ir além daquilo que a própria metafísica do sujeito cartesiano não estava mais à altura de satisfazer: ela não vai para além disso. Em consonância com isso lê-se que ela, enquanto uma "nova racionalidade, no seu combate pela razão, entra em luta com o cartesianismo, em nome do próprio cartesianismo" (CHÂTELET, 1983, p. 17) ${ }^{5}$. A motivação e inquietação 
daquele momento histórico, que se chegou a chamar "esclarecimento (Aufklärung)", mesmo sob o reconhecimento por Kant - essa motivação se dá mais é como uma exigência típica de "maioridade" da razão humana; está em jogo aí, predominantemente, a ousadia e coragem de o homem se assumir como capacidade de raciocinar com acerto e mais plenamente; não está em jogo aí a necessidade de pensar o porquê de o conhecimento na ciência se encontrar vinculado à metafísica e o que, no futuro, deveria resultar dessa implicação entre uma coisa e a outra.

Esse entendimento para se poder pensar o tema relativo às críticas feitas à metafísica aparece fortalecido em argumentos mais diretamente ligados a este assunto. Diz-se, por exemplo que, se recuarmos ao século XVII, vamos compreender melhor o que impulsiona a necessidade e as pretensões de se estabelecer crítica à metafísica no fim da modernidade e na contemporaneidade: "Com a mecânica de Galileu e a difusão de seus processos, em todo o campo da experiência, nasceu uma ideia de ciência que se separou fundamentalmente, dos fundamentos da primeira filosofia, da teoria da substância como o verdadeiro ente" (GADAMER, 1983, p. 92).

O enfoque mais relevante na afirmação citada recai na acusação de separação entre uma coisa e a outra. Ressalva: Não pretendo aqui que se deva apressadamente apenas corrigir o moderno pensamento de ciência pelo que se toma por "primeira filosofia' aristotélica e reler, o que é tomado assim, pela condição moderna de a ciência não poder escapar ao destino da metafísica - de ser 'ciência primeira'. O que pretendo com isso é fazer ver o problema de se separar uma coisa da outra sem mais. Com a expressão "sem mais" quero dizer, sem que se constate aí a disposição imprescindível para continuar perguntando o que vem a ser, de fato, metafísica.

Devemos achar que tal fato veio a contribuir indevidamente com o que resultou disso, destacado por vezes como conteúdo positivista no pensamento contemporâneo. Ajuda a compreender isso reconhecer que, no "pensamento pós-metafísico", a exacerbação típica do elemento positivista corrobora o desvio no empenho de se fazer a devida crítica à metafísica: "A situação da filosofia atual tornou-se intransparente. (...) Tornou-se obscura a posição com relação à metafísica"6. A referência a isso concerne em parte ao que se pretende aqui como o elemento de conteúdo para a crítica à metafísica. A referência serve para se perceber que a natureza de positivo nisso só pode se plenificar como ainda plenificação metafísica - é modo de se absolutizar, no sentido de precisar exercer a função de totalidade do real. No caso trata-se de se empregar cientificidade para significar abrangência - para significar a base de designação de todo e qualquer ente. Por isso pode-se sem grande dificuldade perceber e acusar a ânsia com que o caráter de metafísico escapa ao capricho de quem critica a metafísica e acaba por se fazer predominar inevitavelmente também: "Neste furor antimetafísico revelou-se um motivo cientificista não esclarecido, o de elevar ao absoluto o pensamento científico-experimental" (HABERMAS, 1990, p. 37)7. O que foi feito "premissa" depois do pensamento da dialética hegeliana não teria como conciliar as perspectivas possíveis.

Interessa aqui com isso apenas repetir e frisar a referência à crítica à metafísica que se encontra implicada no cientificismo teórico do positivismo. "Apenas" isso, visto que não está sendo também recusado por Habermas no positivismo a convicção de base matricial moderna considerada suficiente para se efetivar ultrapassagem do caráter metafísico na filosofia. Até mesmo acredita que o positivismo antes "tinha desmascarado" a metafísica (HABERMAS, 1990, p. 37) . Até convém destacar que prevalece como lógica do rigor de teórico positivista o seguinte: podendo a realidade ser explicada pela ciência, passa-se a admitir que, só resta para a filosofia cuidar de uma espécie de fiscalização do procedimento do conhecimento, dos métodos e linguagem de que a ciência precisa. Enfim espera-se que com isso a metafísica possa se autoextinguir, por via óbvia.

Mas não só não ocorre essa extinção da metafísica, como não se consegue evitar que ocorra a renovação da metafísica enquanto sempre uma nova versão sua - a saber, o 
próprio positivismo, - agora como vários positivismos ou neo-positivismos. De alguma forma já se atesta isso quando se acusa "o pensamento científico-experimental" de ser elevado "ao absoluto", enquanto "pensamento científico-experimental". Mas é preciso acrescentar que isso deve ter sua origem em algo anterior. Pertence à gênese comteana do espírito positivista considerar a metafísica, praticamente uma mera fase no curso de realização da razão humana e que seria necessariamente ultrapassável ${ }^{9}$ na evolução do conhecimento teórico-científico; por causa disso supõe-se, depois, poder extinguir definitivamente a metafísica. E no entanto, com base no conhecimento das leis da natureza, apenas reemprega-se aquela objetividade metafísica, que é a única que dá essa validade reivindicada pelo espírito positivista de todos os positivismos.

Visto de outro ângulo, também a pretensão de ultrapassar a metafísica precisa investir também contra elementos de sua própria base como se pudesse ir contra si mesma. Por exemplo, parte dessa busca de ultrapassagem da metafísica se configura como tentativa de ir para além de Kant, mas tendo de contar com Kant enquanto sua própria base. Neste ponto, Gadamer critica o neokantismo, no que o pensamento de Kant é condicionado a uma "interpretação teórico-epistêmica": "Isto, na realidade, soa como se o fato da ciência devesse ser [o] pressuposto e como se a crítica de Kant tivesse querido proporcionar, somente, a fundamentação justificante deste fato" (GADAMER, 1983, p. 88). A lógica, portanto, de se tentar diferenciar entre o saber metafísico e o saber de cientificidade relativa à ciência coexiste com esta indagação: é possível separar uma coisa da outra e em que consistiria a separação? A indagação quer indicar a opção pela resposta negativa: primordialmente não se consegue assegurar separação entre metafísica filosófica e ciência. Por isso, em lugar de investida nesta cientificidade, importa mais que se investigue a existência de interdependência entre ciência e metafísica.

\section{2}

O que fica indicado a partir de Kant (1724-1804) é que os limites da metafísica como conhecimento precisam ser identificados e estabelecidos. Mais exatamente, precisam ser restringidos em relação à validade do conhecimento de ciência. Isto quer significar que o conteúdo de verdadeiro aí não é próprio nem de autonomia da metafísica e sim da teorização inerente ao processo de cientificidade no conhecimento; os critérios para se obter este conteúdo de verdadeiro não se devem neste caso, à incumbência da metafísica.

Este fato seria reflexo e exigência condizentes com o modo de pensar desse tempo - a modernidade. Nas palavras de Kant, "é um apelo à razão para atacar de novo a mais dificultosa de todas as suas incumbências, isto é, a do conhecimento de si mesma..." (KANT [A XI], 1985, p. 14 e 15).

Kant indica que se tem cometido equívoco no emprego da razão humana; ele quer dizer que não está sendo compreendido qual é o papel da razão, no sentido do "conhecimento de si mesma". "A nossa época é por excelência uma época de crítica à qual tudo deve submeter-se" (KANT [A XI], 1985, p. 14 e 15). Nesse entendimento, ele generaliza a necessidade moderna de crítica à própria razão humana. Não quer dizer, porém, necessidade de extinguir a metafísica. A crítica à metafísica que procede disto é peculiar no que precisa assegurar a identidade e necessidade da própria metafísica.

No segundo prefácio da Crítica da razão pura, Kant compara a metafísica com as outras ciências (mais exatamente a matemática e a física) quando se refere à ineficácia do conhecimento metafísico, se for equiparado ao caráter teórico relativo ao conhecimento nessas ciências: a metafísica, também um conhecimento racional especulativo e que se eleva muito acima do ensinamento da experiência, levando a que a razão seja discípula de si mesma, mas nem por isso teria conseguido até então encontrar o caminho seguro de uma ciência, apesar de ser mais antiga do que as outras 
ciências. Kant acusa também o fato de que a metafísica precisa, vez por outra, dar um passo atrás, pois descobre que tomou um caminho em que não se sabe aonde ela quer chegar. E conclui de maneira enfática: "Não há dúvida, pois, que seu proceder até aqui tem sido mero tatear e, o que é pior, entre meros conceitos" (KANT [B XIV-XVI], 1993, p. 27).

Isto, dito em referência à metafísica, bem como a noção de caminho seguro de uma ciência, coincidem entre si e sintetizam o que Kant quer exprimir sobre a metafísica, a saber: para exercer o que tem pretendido, a metafísica teria de poder mostrar a validade de seu saber, de modo a não divergir da validade assegurada pela ciência.

Se tivermos em conta um desdobramento dessas afirmações de Kant, podemos ver aí possíveis, mas forjados motivos pós-kantianos e contemporâneos do "fim da metafísica", pelo menos enquanto influência disso na reflexão filosófica depois de Kant. E isto estaria então na fundamentação das críticas à metafísica na contemporaneidade. Neste sentido, o teor da influência sobre as críticas contemporâneas à metafísica estaria ligado ao caráter de teórico relativo ao modo de ser da ciência moderna.

Mas é necessário acrescentar que o aspecto mais significativo no sentido de problemático se encontra em outro nível, a saber: a própria declaração de Kant, em destaque, indica que ele aspira transformar a metafísica em metafísica - por assim dizer. Ele tem em mira é a metafísica e não propriamente a ciência. Ele mesmo se refere a isto embora indiretamente, por não ser o que está sendo tratado como essencial: é também "de grande importância para o meu objetivo principal" (KANT [A XVI], 1985, p. 20 e 21). Sendo assim é preciso ver melhor porque Kant está a se referir ao "proceder" enquanto método das ciências como sendo o único capaz de assegurar validade na operação racional do conhecimento. Se a metafísica como tal não conseguira até então mostrar nem assumir sua verdadeira posição em relação a este problema, então precisaríamos saber em que sentido a metafísica estava vinculada a esta validade na ciência e em que sentido não estava vinculada.

Há que se perceber aqui algo de muito importante no que Kant está a informar. Pois ele quer apontar para o fato de que a metafísica, sem se dar conta, encerra nela a contradição que é buscar conhecer a realidade sem igualmente examinar o poder de conhecer que ela possui, ou seja, seus limites, e de que modo é que ela se constitui também em conhecimento - ou seja, qual método tem sido empregado por ela e que outro método deveria empregar. O que leva Kant a conseguir fazer esta crítica à metafísica é ter descoberto que a validade objetiva e do método do conhecimento teórico na ciência reside na própria "possibilidade" (Möglichkeit) e "poder chegar a conhecer" (Erkenntniskräften) inerentes a esta mesma validade e método que a ciência possui (Cf. KANT [A XVII], 1985, p. 20 e 21). Kant nos leva a ver os dois aspectos em jogo aí: a metafísica precisar ser metafísica e ter de se corrigir, tendo em vista a validade própria do conhecimento e método na ciência.

Por estar consciente de uma espécie de paradoxo necessário nisso, Kant precisa dizer que sua tarefa aí tem de ser o ocupar-se da validade e método na ciência e não o ocupar-se já e diretamente de examinar a metafísica - apesar de, no fundo, estar a tratar da questão da metafísica. Ele diz isso assim: "embora este exame seja de grande importância para o meu objetivo principal, não faz parte essencial dele; porque o problema principal será sempre o de saber o que e quanto o entendimento e a razão conhecem independentemente de toda experiência, e não o de saber: como é possível a própria faculdade de pensar propriamente" (KANT [A XVI], 1985, p. 20 e 21) - em que consiste no homem ele pensar.

Este "que" e este "quanto" o entendimento e a razão conhecem temos de considerar primeiro pelo ângulo do limitar a razão negativamente; por terem somente a função de condição do conhecimento de experiência se efetivar. Assim é que um caso o entendimento - se diferencia do outro - a razão. Quer dizer: a questão da metafísica 
está na dependência de se estabelecer a diferença entre entendimento e razão e além disso compreender o que cada um destes elementos pode conhecer de fato. A questão de fundo, enquanto a essência da questão toda está no fato de que nosso conhecimento advém de nosso conseguir experienciar, no sentido de que o conhecimento perfaz-se propriamente como a experiência em totalidade. Em meio a isso encontram-se o entendimento e a razão a exercer necessariamente funções relativas a esse conhecimento de experiência, existente em nós, segundo nosso poder conhecer e nossos limites concernentes à razão.

Ora, quando tentamos dizer o que é a realidade das coisas, e na forma de um saber próprio do homem, ou seja, o saber estabelecido sob o modo de ciência, só podemos exprimir isto sempre dentro da circunscrição de nossa experiência, que é o conhecimento a que estamos afeitos, isto é, o conseguir experienciar; é aquilo que nós próprios somos. E agora não devemos esquecer que fazem parte desta circunscrição o entendimento e a razão. Uma diferença entre um e o outro é explicada por Kant, no sentido de que o entendimento nos fornece as condições de determinarmos este conhecimento de experiência, isto é, o conhecimento dos objetos não só como coisas percebidas por nós em razão das impressões com que as coisas nos atingem, mas sobretudo como passam a valer objetivamente como objetos, sob o caráter de universal e necessário. É no entendimento, portanto que se decide o essencial de nosso conhecimento no que concerne à experiência - ou seja, portanto, concernente ao que nós somos. A razão, nesse processo do conhecer, passa a nos interessar e a ganhar importância para nós, enquanto significa a nossa capacidade humana de pensar para além da aparência das coisas, a ponto de poder assegurar no pensamento - isto é, racionalmente - o todo dos objetos determinados pelo entendimento; pois sem a perspectiva de todo para os objetos da experiência, não haveria a ampliação e progresso daquilo que fosse estabelecido pelo entendimento.

Aqui se percebe em que ponto incide o problema e o como ele se agrava: é a razão que aponta para a possibilidade de um perfazer teleológico de totalidade da experiência, mas que não tem como assegurar a validade disso que só conhecemos pelo entendimento que se limita às nossas condições da própria experiência. Em relação a isto estou a me referir a uma necessidade que é referente ao conhecimento próprio à "ciência da natureza" e não relativamente à abrangência toda da metafísica, conforme se pode perceber nesta passagem (KANT [B VIII-XIX], 1985, p. 40 e 41) do prefácio da segunda edição da Crítica da razão pura: seria para se considerar o "para além da experiência", se se "imita", tomando emprestado o "método" do "investigador da natureza", para "procurar os elementos da razão pura naquilo que pode ser confirmado ou refutado por um experimento". A partir daí então 'as proposições da razão pura, especialmente quando se aventuram para além dos limites de toda experiência possível, não admitem qualquer espécie de exame, visto excluírem toda experimentação com seus objetos (ao contrário do que ocorre na Ciência da Natureza)" Na metafísica fícam sem poder ser explicadas essas "proposições da razão pura" e, é porque elas se põem "para além dos limites de toda experiência possível".

Então, o que é esperado nesta relação comparativa feita entre o conhecimento metafísico e o conhecimento na ciência é que, à proporção que se vai precisando e podendo explicar validade e método no conhecimento objetivo de ciência, vai-se podendo explicar também isto mesmo relativamente à metafísica, mas de modo crítico, isto é, contra ela. A questão fundamental aqui é a seguinte: por natureza, a razão - que quer dizer sempre a capacidade humana de conseguir conhecer as coisas - sabe-se capaz de ultrapassar limites e problemas mediante o que pode conhecer, mas também o quanto ela se perceba e se conceba nisso sendo inteiramente ultrapassada por questões que não cabe resolver.

Quando dizemos então validade, isto corresponde ao que Kant chama de "validade objetiva e validade universal necessária" para nós, isto é, para qualquer pessoa. Significa que, o que uma coisa vale para mim, vale também para qualquer outra 
pessoa. Significa que essa coisa detém os elementos que fazem com que ela possa ser entendida assim com esse poder. Logo são características que constituem o essencial do nosso compreender. E este caráter de validade concerne ao "que" o entendimento pode fornecer como tais condições do conhecimento. Assim, aquela relação entre possibilitar "o que" e depender "do que", é que está em jogo aqui, quando é dito por Kant o "que" e o "quanto" o entendimento e a razão conhecem. No que concerne ao entendimento interessa $o$ fato de se priorizar o tipo de conhecimento da experiência como $o$ conhecimento capaz de definir, conceituar. No que concerne à razão interessa o fato de seu duplo papel: o de ser formas puras a priori para as condições do conhecimento e o papel de considerar seus limites em relação a conhecer diretamente a realidade externa.

Duas coisas devem ser realçadas. A primeira é a 'ineficácia' do conhecimento metafísico, no que diz respeito a exprimir validade concernente à experiência e, no que diz respeito a ser prioritária no conhecimento objetivo de experiência - então eficaz para este fim. No caso em questão, o caso do conhecimento metafísico, a natureza da razão está vinculada ao fato de que não podemos conhecer o que é em si nas coisas; está aí então a dependência nossa das condições do conhecimento de experiência. Isso faz com que a metafísica não seja o conhecimento prioritário para definir a realidade, ou seja, o fato de não ser capaz por si só de assegurar uma verdade do mundo para além deste que as condições do entendimento e razão podem conhecer, segundo seus limites e seu poder. A outra coisa é, porém a totalidade incondicionada de que a experiência necessita para ser entendida como experiência; é o fato de que não podemos abolir o em si dos objetos e, além disso, o conhecimento de experiência também depende de formas e condições a priori para sua execução, como também, para se ampliar e progredir precisa igualmente dos princípios e ideias metafísicas como causalidade e totalidade ${ }^{10}$.

Essas duas coisas levam ao que interpreto aqui como a informação mais importante que Kant quer dar a conhecer: a informação de que com a metafísica a razão pode com direito pensar a verdade com base na validade do conhecimento de experiência; e isso quer dizer igualmente tornar possível toda a validade considerada até aqui apenas possível; a validade que o entendimento determina como este mesmo conhecimento de experiência. Em outros termos mais favoráveis à questão em jogo: trata-se do fato de podermos contar com a validade do conhecimento de experiência assegurado pela ciência; no entanto, justo isso faculta - e mesmo, não pode impedir de ir para além de si próprio - não pode impedir que este próprio conhecimento, o conhecimento concernente a experiência, tenha de ir para além de si mesmo.

Há aqui um conflito natural que cria o motivo da questão da metafísica como questão. Tomemos para referência disso uma declaração de Kant que diz:

Para conhecer um objeto é preciso que eu possa provar-lhe a possibilidade (seja
pelo testemunho da experiência a partir de sua realidade, seja a priori, pela razão).
Isto é, que o meu conceito seja um pensamento possível, embora eu não possa
responder pela presença de um objeto correspondente no conjunto de todas as
possibilidades. Mas é preciso algo mais para atribuir a um tal conceito uma
validade objetiva (isto é, uma possibilidade real, pois a outra é meramente lógica).
Este algo mais, porém não precisa ser procurado nas fontes teoréticas do
conhecimento, podendo encontrar-se igualmente nas fontes práticas". (KANT [B
XXVI], 1985, p. 48 e 49, Nota 5)

A conclusão a que isso nos leva é que: [a] inicialmente temos de dar certa prioridade ao conhecimento de experiência; então a metafísica o tomaria como modelo e a seu favor; [b] mas depois temos de admitir que, justo em decorrência disso, também a questão da metafísica acaba por se evidenciar como questão. Com outras palavras, Kant deixa que a questão da metafísica permaneça como questão.

Mas isso tudo é dito assim não só por nos reconhecermos devedores a Kant pelo entendimento disso; é mais para pôr em destaque o elemento do conteúdo de metafísico, para o qual o transcendental está como recurso de contornar o que nele é 
problema. O termo "problema" aqui não exprime algo de negativo e sim algo de inerente ao conteúdo de saber filosófico que tem justificado dependência da metafísica. Por causa dessa dependência, acaba-se podendo indevidamente explicá-lo também em sua condição de externo a ela. Mas deve ser porque isso - esse conteúdo - não tem sua verdade no deixar de ser "problema", mas no contrário disso. Se for assim, o que se consegue contornar mediante o conteúdo de transcendental atende à necessidade de se definir e explicar a condição de como ocorre e se realiza. Trata-se não de sua valência de problemático e sim de sua valência de possibilidade de experiência efetiva, em que "é preciso que eu possa provar-lhe a possibilidade", para que possa chegar a valer o que concebo com meu pensar. Não está sendo dito, a rigor, que a valência de problemático é anulada ou deixa de existir. O que é dito é, apenas, que no "conjunto de todas as possibilidades" suas, eu não tenho como poder fazê-lo valer objetivamente. É preciso notar que está em jogo a operação humana de conhecimento de alguma coisa a partir de - isto é, com - a capacidade de se pensar tudo o que pode ser pensado. Então pode-se perceber aí a mistura de uma coisa com a outra - conhecer enquanto delimitar; pensar, enquanto poder abranger o todo dessas coisas. Justifica-se que se estabeleça a motivação e necessidade da forma crítica de raciocinar, sem o que pode ocorrer de passar a valer objetivamente o que foi apenas pensado. No que concerne à questão em estudo - ao problema da metafísica -, em última instância então não só nunca se extingue a valência de todo enquanto natureza do conteúdo do saber filosófico, como subjaz ela sempre na valência da objetividade.

Também procede já de David Hume (1711-1776) crítica à metafísica na modernidade. Ele dá a entender que a razão em nós é tão poderosa em nos enganar, que não percebemos o quanto ela invade nossa compreensão e certeza, a ponto de falseá-las em relação à verdade que atribuímos à realidade das coisas. Somos enganados pela razão, ou seja, não nos damos conta de como nosso entendimento é sequestrado pela "influência do costume"; ela "encobre" "nossa ignorância natural", quando atribuímos ao conteúdo de causa a verdade do conteúdo de seu efeito" ${ }^{11}$.

Tal concepção espelha um tempo em que o conteúdo de neutralidade para a verdade no conhecimento tende a ser uma exigência que se encontre na alçada do próprio entendimento humano; algo que se dê como certeza e seja capaz de comprovar a validade do conhecimento, porque se torna ineficaz ainda continuar a procurar isso na razão, ao considerá-la divina. O curioso nisso é que passamos a ser enganados por nossa própria razão, que é a fonte de todo conhecimento.

Preciso frisar aqui que é a própria razão que nos engana e, neste caso então seria preciso investigar propriamente a razão. Kant percebe isto e passa a examiná-la quanto a seus limites. Mas Hume, quando se refere à experiência como conhecimento, não já chega a fazer a mesma coisa; não lhe ocorre de elaborar a implicação entre uma coisa e a outra; as funções de uma - a saber, da experiência, teriam simplesmente de tomar o lugar das funções da outra - da razão: “... as causas e os efeitos não são descobertos pela razão, mas pela experiência ...” (HUME, 1980, p. 144). Neste caso, ainda que como crítico do conteúdo de metafísico Hume, todavia, não reage à lógica que se encontra intrínseca ao conteúdo próprio de categoria no modo aristotélico de compreender, que ele precisa empregar para constituir a relação causa e efeito como proposição do conhecimento de experiência. Observação que podemos fazer a partir de e graças a Kant, com vistas ao conteúdo de transcendental.

Mas na dificuldade apresentada por Hume requer que se note algo a mais, além da correção kantiana. Quando percebemos a razão a nos enganar, isto quer dizer não só uma falha da razão e sim o como o homem tem de tratar as coisas - o como ele tem de determinar o que vê e percebe; o como ele tem de determinar por real, por realidade aquilo em que ele está inserido; na verdade, é o como ele tem necessariamente de viver, pois este viver é o seu ver, no sentido de ter de saber ser o que ele é. Este "como" vem a ser o saber, o conhecimento. Em outras palavras: é o conhecer no modo de produzir conhecimento, ciência, saber, uma vez que isto é o humano ver-se e ser-se no perceber 
as coisas. A filosofia busca ser este saber - aqui então enquanto metafísica. Trata-se, antes de tudo, de ser uma das formas de saber teórico - como o são os saberes em que se alcança a verdade pelo conhecimento da causa de alguma coisa ou fato. Isso se estabelece como uma resolução humana a ser tomada, - caso se veja aí uma espécie de parecer de Aristóteles sobre este assunto. O parecer consiste em que é preciso uma resolução que faça passar para o grau de teorético aquele ver inevitável, ou seja, aquela percepção, que ajunta num todo só as coisas atingidas pelo perceber. O homem terá de processar este perceber deixando o pensar demorar prioritariamente no ajuntar as coisas num todo, a ponto de passarem a ser contempladas pela implicação de pertencimento a este todo. As coisas ganham a determinação própria neste processo de fazê-las refletir um todo. Mas isso quer dizer que a unidade de todo aí se torna causa e verdade teorética.

O grau de teorético nisso consiste no conteúdo de "puro", neutro, livre. Isto compreendido na diferenciação com o significado de algo dado em vez de algo contemplado. $\mathrm{O}$ conteúdo de puro relativo a teorético possui caráter de divino. $\mathrm{O}$ teórico em qualquer outra ciência já existe na condição de derivado deste sentido de puro. É que enquanto cada coisa cumpre sua função, isto é pensado como seu grau primeiro e último de essencial (bem). Também vale para o homem, mas com a diferença de que isto se dá aí pelo buscar a verdade de sua destinação; não se dá em razão de ele buscar ser uma coisa, - a coisa-homem. Neste sentido declara Aristóteles: "Seria estranho, com efeito, se o homem devesse dar preferência não a viver a sua própria vida, mas a vida de outro ser qualquer" (ARISTÓTELES [1178 a], 1992, p. 203) Com esta afirmação, ele diz, no entanto, que a felicidade que o homem busca em sua vida concerne não ao desejar ser como as coisas, mas como algo divino que o homem constata em si próprio. Em razão disso, seu saber é, em primeiro lugar, o da busca da causa referente a este princípio divino, causa primeira e última. É a ciência da totalidade possibilitadora de determinação de tudo o que se encontra dado como coisa ou ente. Aqui reside a pergunta: o que é essa totalidade enquanto ela própria? No homem, o que lhe possibilita este tipo de saber e de vida desejada é a razão. Enfim é este o papel da razão. Significa que, na condição de consequência, a razão resulta em elemento divino no homem - no sentido aristotélico de que "o homem", mais do que qualquer outra coisa é a razão. (Cf. ARISTÓTELES [1178 a], 1992, p. 203).

$\mathrm{Na}$ medida em que Hume depende da lógica aristotélica, não escapa à circunscrição da respectiva origem da razão. Se a causalidade lhe soa como um engodo da própria racionalidade, não se livra dela todavia pelo mero rebelar-se contra a razão. Aquela lógica ainda está em sintonia de coerência com o princípio da substância como primeiro motor. No caso é suficiente uma lógica em que se possam derivar categorias a que as coisas obedeçam, para que cada uma delas possa ganhar determinação própria. É o modo de predicar algo, isto é, de determinar de antemão designação para algo, seja com referência à quantidade, qualidade, qüididade, modalidade, tempo e lugar etc. Assim, a totalidade que é enquanto ser, também se dá em vários sentidos - segundo categorias lógicas do dizer enquanto linguagem.

O fato de a razão, antes de qualquer outro ente, exprimir o que o homem é, diz bem como a tradição pôde dispor de uma base, a partir disso, para preservar a seu modo a compreensão de razão: seu significado está conectado ao sentido de diferença específica, relativamente ao homem decidir ser "sua própria vida" e não "a vida de outro ser qualquer". Significa que nosso entendimento a partir disso logo se ocupa com o caráter da especificidade que o homem possui em relação aos outros entes. A noção de diferenciação, tal como a utilizamos o mais racionalmente possível, leva a alcançar algo que revele sua identidade, seja pela semelhança, a exemplo da "imagem e semelhança" de Deus; seja pela semelhança segundo o poder da razão. Mas, a mencionada afirmação diz mais duas coisas: diz o caráter enigmático inerente ao conteúdo de divino e a condição humana de errar, inerente à razão. Nenhuma das duas indica poder ser eliminada com a crítica à metafísica. A partir desta conjuntura de cunho 
aristotélico podemos deduzir que vem de muito tempo atrás - vem já com a origem do homem - o fato de que a razão nos engana. Pelo mesmo motivo, pois, teria de continuar assim, também depois de Hume, dentre outros críticos.

$\mathrm{Na}$ afirmação de que "a razão, mais do que qualquer outra coisa, é o homem" é como se o pensador buscasse mais exatidão para equilibrar seu dizer: a razão é o

34 homem ou o homem tem de ser sua razão? Mas basta que estabeleçamos esta formulação assim, para que se passe da conta em relação ao essencial disso; ele desaparece. É porque se trata de uma coisa só o essencial que nos atinge nisso e nos impele a buscar equilíbrio: é a contingência em que estamos - nós, o homem inseridos. $\mathrm{Na}$ especificidade da reflexão aqui, isto quer dizer: o homem não pode não ser essa contingência. Em outros termos, ele é razão no sentido de continuar tendo de ser contingente e não ser já, mas falsamente, um deus. A razão, então, precisa ser algo sempre em relação a isto - o mundo contingente -, diferentemente do que pretendeu ser na modernidade.

Esta referência à razão aqui se conecta ao dizer de Aristóteles de que o homem se conduz no saber não pela parte do que ele é enquanto a irracionalidade, mas a racionalidade de sua alma (Cf. ARISTÓTELES [1139a], 1992, p. 113).

$\mathrm{Na}$ sequência, é na parte da racionalidade da alma que se dá o exercício de conhecimento possível de se categorizar segundo a condição de lidar com as coisas enquanto realidade mutável e nela se conduzir: na categoria de "excelência intelectual" - por exemplo "a sabedoria, a inteligência e o discernimento"; na de "excelência moral" - por exemplo a liberalidade, a moderação", etc. (cf. ARISTÓTELES [1103a], 1992, p. 33). Na sequência, é na excelência intelectual" que vamos enfim encontrar a identidade do saber metafísico e qual é a sua função, relativamente à razão - e ao homem: elevar à "atividade divina" (cf. ARISTÓTELES [1178b], 1992, p. 205) sua atividade mutável e contingente, na forma da "sabedoria filosófica". Na sequência como conclusão, é numa ambivalência que reside o essencial de tal saber: coexistência de "razão intuitiva" ("inteligência") e demonstração teorética ("ciência"). Dificuldade decorrente: o caráter de positivo da ambiguidade não se deixa firmar como síntese de mutável, teorético e divino; o de negativo não impede o predomínio de teórico-científico sobre o mutável sob validade de universal e em detrimento do por si divino. Como consequência, a crítica à metafísica na modernidade está na condição de não perceber nem estabelecer esta diferenciação.

No entanto foi considerada a coexistência das duas valências. A instrução relativa ao conteúdo de razão se reforça com esta outra afirmação: o mais relevante não é que o homem seja superior aos "animais", visto que "há outras coisas muito mais divinas em natureza que o homem..." (ARISTÓTELES [1141a28], 2011, p. 291). Donde a verdade do saber em questão requer que ele se dê não só como "ciência", mas também como "intuição racional” (como alcance do que é por si e divino).

\section{REFERENCIAS}

ARISTÓTELES. Ética a Nicômaco (livro VI). Tradução de Lucas Angioni. (Dissertatio [34] 285 - 300 verão de 2011) http://unicamp.academia.edu/LucasAngioni (Em 21.02.2016).

Ética a Nicômacos. Tradução de Mário da Gama Kury. Brasília: Editora Universidade de Brasília, c1985, 1992, $3^{\text {a }}$ ed.

Metafisica. Tradução de Valentin G. Yebra. Madri: Editorial Gredos, 1987. (Edição em grego, latim e espanhol)

CASSIRER, Ernst. A filosofia do iluminismo. Tradução de Álvaro Cabral. Campinas: Editora da UNICAMP, 1994, $2^{\mathrm{a}}$ ed.

CHÂTELET, François. O iluminismo (século XVIII). Tradução de Maria Hena Couto Lopes e Nina Cosntante Pereira. Lisboa: Publicações Dom Quixote, 1983. Coleção História da filosofia, idéias, doutrinas, $\mathrm{n}^{\circ} 4$. 
COMTE, Augusto. Curso de filosofia positiva. Tradução de J. A. Giannoti. São Paulo: Abril Cultural, 1979, (Coleção Os pensadores).

GADAMER, Hans-Georg. Filosofia ou teoria da ciência. A razão na época da ciência. Tradução Ângela Dias. Rio de Janeiro: Edições Tempo Brasileiro, 1983, p. 88-104.

HABERMAS, Jürgen. Pensamento pós-metafísico: estudos filosóficos. Tradução de Flávio B. Sibeneichler. Rio de Janeiro: Tempo Brasileiro, 1990.

HUME, David. Investigação sobre o entendimento humano. Tradução de Leonel Vallandro, São Paulo: Abril Cultural, 1980. (Coleção Os pensadores).

KANT, Immanuel. Kritik der reinen Vernunft. Stuttgart: Reclam, 1993.

Prolegômenos. Textos seletos. Tradução Tânia Maria Bernkopf. São Paulo: Abril Cultural, 1980. (Coleção Os pensadores).

Textos seletos. Tradução de Raimundo Vier e Floriano de Sousa Fernandes. Petrópolis: Vozes, 1985, 2a ed. (Edição bilíngue Alemão-Português)

REINER, Hans. O surgimento e o significado original do nome Metafisica. Sobre a metafísica de Aristóteles: textos selecionados. Coordenação de Marco Zingano. São Paulo: Odysseus Editora, 2009, pp. 93-122.

VATTIMO, Gianni. O fim da modernidade: niilismo e hermenêutica na cultura pós-moderna. Tradução de Eduardo Brandão. São Paulo: Martins Fontes, 2002.

1 Costuma-se ressaltar que o título "metafísica" não foi criado por Aristóteles; teria sido instituído por quem, já depois da morte de Aristóteles, veio a lidar com o processo de organizar os textos da obra do filósofo. É inevitável que isso leve à discussão em que sentido o conteúdo inerente ao termo metafísica procede deste processo. Em relação a isso requer aqui reconhecer e considerar o debate e aprofundamento do assunto pelos especialistas respectivos, mas no sentido de que, graças a isso, podemos nos referir já diretamente ao que resultou estabelecido, finalmente, pelo título de metafísica e enquanto a própria filosofia. Dito de outro modo, graças à evolução do debate posso, em relação a esse título, priorizar o fato de ter se tornado o elemento provocador do processo e da necessidade de se ter estabelecido no final a designação de metafísica para a filosofia. Assim, os autores vinculados a esta providência, a exemplo de Andrônico de Rodes e, a providência mesma, não é o que precisamos tomar pelo decisivo. Interessa antes o que se pode detectar desse conteúdo que veio a ser considerado filosófico e, neste sentido, pôde ser mantido e resguardado através do conceito de "metafísica". Particularmente para a presente abordagem vale frisar na explicação trazida pelo debate o seguinte: a expressão metò tò fusika/ é tomada no sentido da "Ciência Primeira" e, o conteúdo de primeiro e princípio nisso exprime - inversamente - o que é anterior e mais fundamentalmente na ordem do conhecimento [compreender] do que da ciência da natureza (física) (Cf. REINER, 2009, p. 95ss). Mais claramente: “... Aristóteles teria primeiro tratado das coisas físicas, pois essas, embora sejam posteriores segundo a natureza ( $\tau \tilde{n} \phi v ́ \sigma \varepsilon \imath)$, são

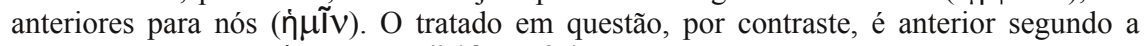
natureza... mas posterior para nós" (ib., p. 97).

2 Emprego aqui a referência aos Segundos analíticos (71b 33ss) feita por H. REINER. A passagem que ele cita resulta em esclarecimento procedente do próprio Aristóteles: “ 'o anterior $\left(\pi \rho \tau_{\varepsilon} \rho \alpha\right)$ e mais conhecido $(\gamma \nu \omega \rho \mu \omega \omega \tau \varepsilon \rho \alpha)$ é de dois modos: o anterior

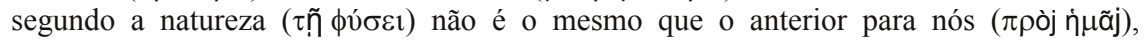
tampouco o mais conhecido (sc. em absoluto) é o mesmo que o mais conhecido para nós. Quero dizer com anterior e mais conhecido para nós o que é mais próximo da percepção sensível e com anterior e mais conhecido em absoluto' - aqui consta $\dot{\alpha} \pi \lambda \tilde{\omega} j$ em lugar de ( $\tau \tilde{n} \phi v ́ \sigma \varepsilon \imath)$ - 'o que, por contraste, é mais distante dela. O mais distante dela é o mais

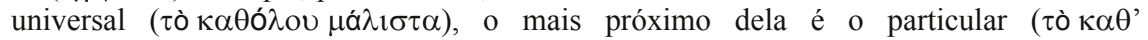

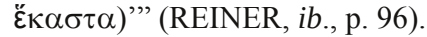

3 Para exemplo tenho em vista as influências, na contemporaneidade, de pensadores como Nietzsche e Heidegger e respectivas consequências de seus desdobramentos. Isso, no sentido de indicarem necessidade do ir além do caráter só "parcial" dessa crítica moderno-contemporânea enquanto "negação de estruturas estáveis do ser, a que o 
pensamento deveria recorrer para 'fundar-se' em certezas não-precárias" (VATTIMO, 2002, p. VII).

4 Ao mesmo tempo que nasce como filosófico, cai na dependência da lógica de universal, como condição para se manter no filosófico. Isto advém das dificuldades inerentes à própria coisa em questão. É preciso não permanecer no próprio impasse, aludido por Aristóteles como um 'nó', que só saberia desatá-lo quem o conhece; quem possui o conhecimento que lhe corresponde. (Cf. ARISTÓTELES [995a], 1987, p. 98). Mas o saber "desatá-lo" é ainda só caminho na direção de um alvo; é conhecimento que, se tomado na obediência irrestrita ao universal, torna-se indevidamente o essencial para a crítica à metafísica.

5 Convém acrescentar também que o pensamento da época iluminismo, em sua base, implica sobremaneira a dependência de legitimidade que, anteriormente, a metafísica era capaz de garantir; depende do teor de legitimidade que a filosofia daquele momento precisa para assegurar os avanços e o progresso que tanto almeja, inclusive em relação ao caráter de teórico da ciência. Assim, a legitimação conseguida antes através do conteúdo de metafísico, acaba por continuar tentando legitimar depois o que se busca na direção do conhecimento de ciência. Isso é o que indica a perspectiva de crítica à metafísica, a saber, a demanda a partir daí por um conhecimento novo, mas que só pode ocorrer se alcançar a devida autonomia, no sentido de poder legitimar a verdade de seu conteúdo. Nesse caso existe a relação de dependência da metafísica entre a filosofia do "esclarecimento" e a da substância do sujeito. É questão apenas saber como a razão precisa ser concebida: não mais como a "soma das 'ideias inatas', anteriores a toda a experiência, que nos revela a essência absoluta das coisas", mas como a capacidade de interferir nessa "soma", no sentido de poder decompor e recompor o todo da experiência que é compreendida e explicada nisso. Está em jogo poder dominar o conhecimento da totalidade da experiência: "A razão desliga o espírito de todos os fatos simples, de todos os dados simples, de todas as crenças baseadas no testemunho da revelação, da tradição; só descansa depois que desmontou peça por peça até seus últimos elementos e seus últimos motivos, a crença e a "verdade pré-fabricada"'. Depois disso, porém, a razão reconstrói o "edifício", já com "regra" criada por ela mesma e, desse modo tornando-se ela própria, por fim, um "duplo movimento intelectual"; agora "não como a ideia de um ser mas como a de um fazer" (Cf. CASSIRER, 1994, p. 32-33). A perspectiva de desenvolvimento futuro da crítica à metafísica, desse modo, passa a investir em determinada psicologia em lugar da metafísica - relativamente à teoria do conhecimento.

$6 \mathrm{O}$ autor continua a declaração dizendo: "Durante longo tempo fora clara a posição do positivismo e de seus seguidores: ele tinha desmascarado os questionamentos da metafísica como destituídos de sentido - enquanto tais, eles podiam ser postos de lado" (HABERMAS, 1990, p. 37).

$7 \mathrm{Id}, \mathrm{ib}, \mathrm{p} .37$.

8 É criticado só o procedimento: "Eu penso na disputa em torno de uma premissa, tomada após Hegel como ponto de partida por todas as facções". "Não me refiro à disputa das escolas, que sempre foi o meio propício ao desenvolvimento do filosofar" (Id, ib, p. 37).

9 A razão, no estágio positivista, reconheceria "a impossibilidade de obter noções absolutas" e, assim, não iria mais "procurar a origem e o destino do universo", mas "preocupar-se unicamente em descobrir, graças ao uso bem combinado do raciocínio e da observação, suas leis efetivas, a saber, suas relações invariáveis de sucessão e de similitude" (Cf. COMTE, 1978, p. 4).

10 A razão cumpre nisso a função de uma síntese entre as condições da experiência e a totalidade incondicionada de que a experiência necessita para se entender como experiência.

11 Cf. (HUME, 1980, p. 145). 